\title{
Udmurdi laulutekstid teabeallikana
}

\author{
Irina Nurijeva
}

Traditsiooniline udmurdi laul, mis aktiivselt funktsioneerib tänapäevase kalendri- ja perekonnakombestiku süsteemis, on üks olulisemaid teabeallikaid. Laulutekstide poeetilised sümbolid ja kujundid aitavad sügavamalt avada rituaali semantikat, kindlaks määrata selle struktuuriosade vastastikuseid suhteid ja peegeldavad traditsioonilise mõtlemise eripära.

Rahvaluuletekstil on erinevad informatiivsuse tasandid, see on suurelt osalt tingitud nende "mitmekihilisest" struktuurist, arhailisele põhjale hilisemate lademete lisandumisest. Kui ühtede kujundite tähendus on läbipaistev, siis teiste semantika osutub tänapäevasele esitajale ja kuulajale tihti šifreerituks.

Viimast laadi tekstidest on võimalik informatsiooni saada siis, kui uurida neid esituse kontekstis. Viisi ajaline kuuluvus ja selle seotus kindla kohaga seletavad ühe või teise laulus esineva kujundi, sümboli ja motiivi kasutamist. Siirderiituste puhul on oluliseks täpsustavaks parameetriks esitatava teksti adressant, kelleks või milleks rahvalaulikud antud olukorras end kujutlevad.

Pöördume konkreetsete näidete poole. Alnaši rajooni Udmurt Višuri külas on üles kirjutatud järgmine mälestamislaulu Йыр-пыд сётон гур tekst:

Возьмало, дыр, возьмало, дыр, возь калыкъёс Вуозы ини ӧтьылэм куномы шуса.

Ой, лапегесь ук, лапегесь возь выл калыкъёс. Пидсаса но кырмамы, ой, нонокъёссэс.

Ilmselt ootavad, ilmselt ootavad luhainimesed, öeldes: tulevad juba meie kutsutud külalised. Oi, madalakesed ju, madalakesed on luhainimesed, põlvitades ju puudutasime nende rindu (Boikova \& Vladõkina 1992: 108).

Kui lähtuda rituaali peamisest funktsioonist - surnud esivanema mälestamisest -, siis sobivad nii luhainimeste kujund sealpoolse ilma tähistamiseks kui külaliste rituaalsele pidusöömingule ootamise motiiv (viimane on kõigi võõruslaulude olulisim element) ma-

http://haldjas.folklore.eeltagused/nr24/nurieva.pdf 


\section{Irina Nurijeva}

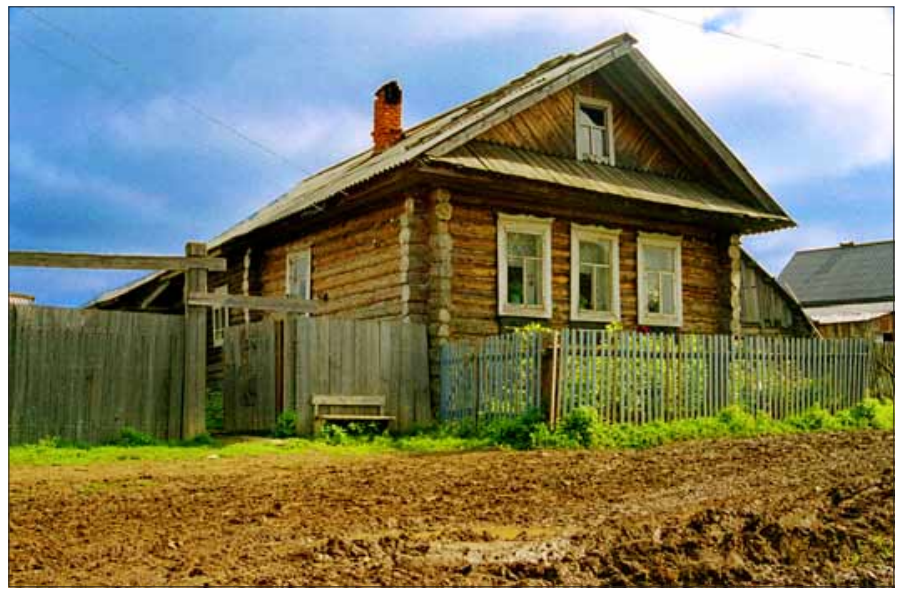

Foto 1. Junda küla. Foto Andres Kuperjanov 2000.

tuse- ja mälestuslaulude tsükli raamidesse. Kahtlema panevad värsid ilmsete erootiliste motiividega:

Ой, лапегесь ук, лапегесь возь выл калыкъёс.

Пидсаса но кырмамы, ой, нонокъёссэс.

Oi, madalakesed ju, madalakesed on luhainimesed, põlvitades ju puudutasime nende rindu. ${ }^{1}$

Kas võib neid pidada udmurdi rahvaluules haruldase, kuid maailma traditsioonilises kultuuris üsna levinud nn surmaerootika näiteks? Kõik saab täiesti selgeks, kui võrdleme selle erinevates rituaalsetes kontekstides esinevaid erinevaid nimetusi (йыр-пыд сётон гур mälestamisel, бӧрысь гур pulmas ${ }^{2}$ ), niisiis kandva polüfunktsionaalse viisi tekste:

Ой, лапегесь, лапегесь тиляд ныллёсты.

Питсаськыса кырмаськом, ой, ноноксэс.

Ой, $\square$ ужытэсь, $\square$ ужытэсь тиляд пиёсты.

Чеччыса но чупаськом, ой, бамъёссэс.

Oi, madalakesed ju, madalakesed on teie tüdrukud, põlvitades, oi, puudutame nende rinda.

Oi, pikad, pikad on teie poisid,

üles hüpates ju suudleme nende põski (Бӧрысь гур (pruudi 
sugulaste pulmalaul), Alnaši rajoon, Udmurt Višuri küla Boikova \& Vladõkina 1992: 92).

Peigmehe küla poiste kiitmine ja oma tüdrukute häbistamine või alandamine pulmarongiga tulevate pruudi sugulaste poolt on tüüpilised pulmalauludes esinevad ülistamise ja hurjutamise motiivid, mis üleviidutena täiesti teise rituaalsesse konteksti, luhainimeste - sealpoolse ilma esindajate - kohta kasutatuna omandavad üpris kummalise kooskõla.

Teine näide on kalendrikombestikust. Juuni algul korraldavad Vjatka-tagused udmurdid nn kevade ärasaatmise rituaali. Ööl vastu semikut kogunevad noored küla serva, tavaliselt metsa, ja tulevad sealt, tõrvikud käes, külla, lauldes kalendrilaulu Семык уй сямен

(Semikuöö, st nelipüha viis). Laulu esimene salm on traditsiooniline ning seda korratakse alati väga täpselt:

Изиськод медам, эшъёсы?

Пукиськод медам, эшъёсы?

Изид ке, вӧтад мед пыроз,

Пукид ке, тодад мед усёз.

Või te magate, sõbrad?

Või istute üleval, sõbrad?

Kui magate, unes las ilmume,

kui üleval istute, meeles las oleme (Nurijeva 1995: 105).

Stroofi korduvus samas rituaalses olukorras ning selle funktsionaalne tähtpäevaga seotus Vjatka-taguste udmurtide laulutraditsiooni meloodiate mitmetekstilise funktsioneerimise tingimustes tunnistavad, et tegemist on võtmetekstiga, mis tähendab, et see peab sisaldama rituaalsele tegevusele tooni andvat informatsiooni. Pealmine kihistus - pöördumine sõprade poole palvega neid meenutada - ei reeda teavet, mis võiks avada selle varjatud tähendust. Vaatleme viisi ajalist kuuluvust. Juunit, mida udmurdid nimetavad инвожо (taevased talisted), ${ }^{3}$ peetakse pühaks üleminekuajaks, kesköö on aga sealpoolsete jõudude, surnud esivanemate aeg. Metsast külla suunduvat protsessiooni tuleb selles kontekstis vaadelda kui üleminekut võorralt alalt omasse, omasesse ruumi. Antud rituaalse müsteeriumi puhul, kus aja ja ruumi piirid on kaotatud, on laulu tekst nende vaimude tungiv meeldetuletus, kelle nimel võib-olla laulavadki rituaali kaasaegsed osalised. Järgmine päev - семык - on täielikult pühendatud surnud esivanematele: 


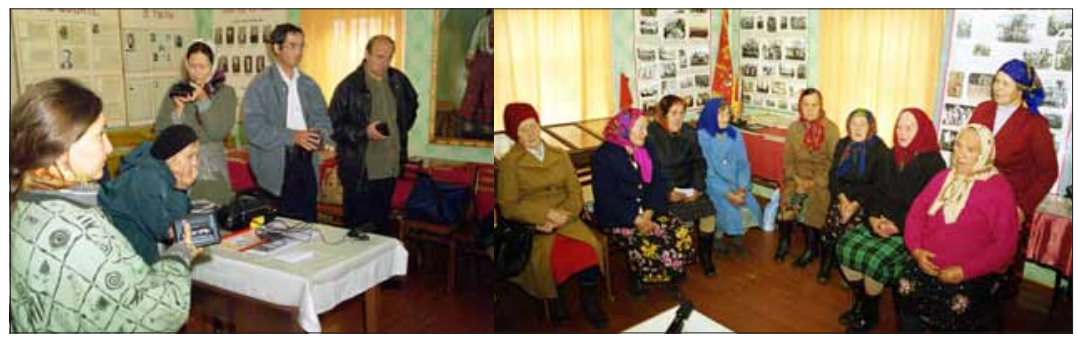

Foto 2.Artiklis kirjeldatud "sõnadeta" laulmist lindistavad udmurdi ja komi folkloristid Tatjana Popova, Jelena Boikova, Irina Nurijeva ja Pavel Limerov. Lauljateks on bessermani naised omarajatud koduloomuuseumis Junda külas. Andres Kuperjanovi foto 2000.

pärast rituaalset saunaskäimist tuleb külarahvas surnuaeda omakseid mälestama. Seda arvesse võttes "kõlab" üleskutse mäletada teistmoodi.

Maailma pärimuskultuuris (eriti põhjarahvastel) eksisteerib ka teine liik laule - refrääniliste sõnadega, ilma tähendusliku tekstita. Selline "tekstivaba" laulmise traditsioon on laialt levinud põhjaudmurtide ja bessermanide juures ning saanud kindla žanrilise määratluse rahvaterminoloogias: udmurdid nimetavad "sõnadeta" laulmist крезь/голос, harvem кыр ${ }^{T м}$, süžeega laule aga мадь. See liik udmurdi tavandilaule ("tekstita", s.t êðåçü) eeldab teistsuguseid analüüsimeetodeid. Üks neist on etnolingvistiline rekonstruktsioon, üksikute sõnade või sõnakombinatsioonide etümoloogiline analüüs, mis taastab vanade rituaalsete laulude kadunud tähenduse. See meetod on efektiivsem tekstiliste vormelite puhul. Nii näiteks lubas katse Vjatka-taguste udmurtide pulmalaulu refrääniga ай дон, mille analoogiks põhjaudmurdi "sõnadeta" lauludes on ай дон / ай дон, esitada hüpoteesi selle vormeli maagilisest, loitsulisest iseloomust ning dešifreerida selles vana Looja poole pöördumise vorm (Nurijeva 1999: 71-76).

Siiski pole põhjaudmurdi "sõnadeta" laulude verbaalne tasand ühesugune, vaid koosneb mitmest leksikaal-grammatilisest reast: leksikaalsetest tähenduslikest kiilunditest, verbidest, partiklitest, hüüd-, side- ja määrsõnadest, abimäärsõnadest, onomatopoeetilistest ja asemantilistest sõnadest, mis võivad olla ammu oma tähenduse kaotanud (Hodõreva 1996: 9). Laulmise käigus kaotavad kõik sõnad, välja arvatud üksikud tähendusega kiilundid, oma tähendu- 
se, muutuvad üksikute lekseemide mõttetuks kombinatsiooniks, mistõttu asemantiliste või arhailiste sõnade etnolingvistiline rekonstruktsioon ei ava lauluteksti loogikat.

Sel juhul on nähtavasti kohasem teine analüüsimeetod - selliste "mitteinformatiivsete" tekstide toomine tänapäeva keeletasandile, traditsioonilise laulu emotsionaalse sisu avamine esitaja sõnade järgi. Sellise üsna õnnestunud katse sooritas bessermani "sõnadeta" lauludega A. Šahhovskoi. Tema arvates võib krezide sõnarida pidada klassikaliseks folkloorse keelekoodi näiteks, mis nõuab (võrreldes süžeeliste laulutekstidega) täiendavat "dešifreerimist" (Šahhovskoi 1998: 109-110). Tema meetod seisneb lauldud teksti "lisamõtestamises", kahe plaani - mõeldava (silmaspeetava) ja esitatava (kõlava) - eristamises. Sel kombel on dešifreeritud mõned "sõnadeta" laulud:

Pruudi tervitamise laul:

Год, год, год, год бен но,

Эй-я, год, меда но.

Эй, ялэ, э, бен, э, меда.

Sõnasõnaline tõlge:

Naine, naine, naine, naine, ja (ju), ja (aga, kuid).

Hei, naine, ainult (ju, või), ja (aga, kuid).

Hei, laske käia, eh (ah, oh), ja (ju), eh (ah, oh), ainult (ju, või).

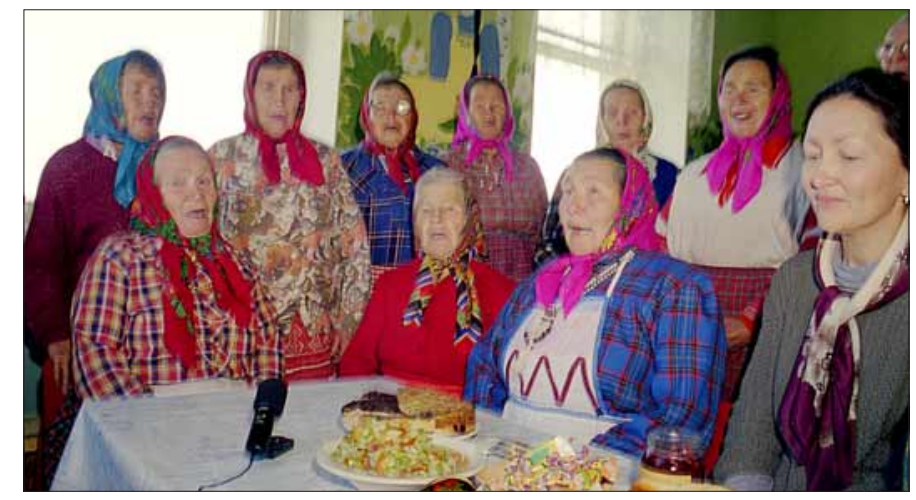

Foto 3. Udmurdi naised koolimajas laulmas. Paremalt esimene on artikli autor Irina Nurijeva. Andres Kuperjanovi foto 2000. 


\section{Irina Nurijeva}

Mõeldav tekst:

Naiseks (said sa nü̈̈, tütreke).

Naine (oled nü̈̈d oma mehele, oled ise majas perenaine).

Laske käia (kallid külalised, joome mu tütre terviseks, soovime talle armastust, õnne, tervist, ilusaid lapsi, küllust majja).

Nekruti koduga hüvastijätmise laul:

У, ку, ку, ку,

Ky, $к y, k y, k y, ~ y$.

Ky, ку, ку, ку, ку,

Пар вало, яла, я.

Ялэ, илэ, ла.

Эй-Я, эй-я, е.

Пар валъёстэ.

Sõnasõnaline tõlge:

Oh (uh) millal, millal, millal.

Millal, millal, millal, millal, oh (uh).

Millal, millal, millal, millal, millal.

Paar hobuseid, las käia, olgu.

Laske käia, laske käia, la.

Hei, hei, ee.

Paar hobuseid.

Mõeldav tekst:

Oh, millal (näen ma jälle sind, mu sünnimaja, lähen sõjaväkke, sõidan ära võõrale maale).

Millal (näen ma jälle teid, mu isa ja ema, vennad ja õed; kas peate mind meeles).

Paar hobuseid, las käia (rakendage, viige mind sünnimajast ära).

Hei (lähen aega teenima: jää hüvasti sünnimaja, hüvasti isa ja ema, hüvasti vennad ja õed, hüvasti kallid naabrid).

Paar hobuseid (ootab mind juba väravas, sõidan kauaks võõrsile, hüvasti, sünnimaja) (Šahhovskoi 1998: 110-112).

Vaatamata kirjeldatud analüüsimeetodi efektsusele ei maksa seda ilmselt absolutiseerida. Oma välitööde praktikas on meil tulnud 
korduvalt kokku puutuda sellega, et erinevates rituaalsetes situatsioonides lauldavates erinevates "sõnadeta" lauludes kasutavad laulikud ühtesid ja samu harjumuspäraseid sõnakooslusi, üht ja sama sõnalist malli. Sel juhul oleks loogilisem asemantilise voo täielik "tõlkimine" teadaolevate emotsioonide järgi. Pealegi on eksisteerimisõigus ka teistel hüpoteesidel, näiteks ideel, et põhjaudmurdi "sõnadeta" laulude tekstid jäljendavad pillimängu, on laulmine "keele saatel" (Agre 1984).

Et mõista kõnet, tuleb aru saada keelest. On selge, et põhjaudmurdi "sõnadeta" laulude uuringud peavad seotud olema eelkõige uuringutega keelest kui helilise suhtlemise süsteemist ja selle funktsioneerimisest konkreetses laululises keskkonnas.

Tõlkinud Aado Lintrop

\section{Kommentaarid}

${ }^{1}$ Нонок (udmurdi k) 'tiss, naise rind' (tõlk).

${ }^{2}$ Nagu teada, markeerib pulmaviis udmurtidel kaht inimelu olulisimat etappi: pulma ennast ja suurt mälestamist, viimasel juhul fikseerides surnu ülemineku individuaalse eksistentsi valdkonnast üldisesse esivanemate valdkonda (Tolstaja 1985: 81).

3 Talvine, jõulust kolmekuningapäevani kestev pööriaeg kannab udmurtidel nime вожодыр (tõlk).

\section{Kirjandus}

Agre 1984 = Агре, В. В. Обрядовые песни без слов северной Удмуртии. Дипломная работа. Свердловск: Уральская государственная консерватория.

Boikova \& Vladõkina 1992 = Бойкова, Елена \& Владыкина, Татьяна. Песни южных удмуртов: Материалы и исследования 1: Удмуртский фольклор. Ижевск: Удмуртский Институт Истории, Языка и Литературы УpO PAH.

Hodõreva 1996 = Ходырева, Марина. Песни северных удмуртов 1. Удмуртский фольклор. Ижевск: Удмуртский Институт Истории, Языка и Литературы УрО РАН.

Nurijeva 1995 = Нуриева, Ирина. Песни завятских удмуртов 1. Удмуртский фольклор. Ижевск: Удмуртский Институт Истории, Языка и Литературы УpO PAH. 


\section{Irina Nurijeva}

Nurijeva 1999 = Нуриева, Ирина. Музыка в обрядовой культуре завятских удмуртов: Проблемы культурного контекста и традиционного мышления. Ижевск: Удмуртский Институт Истории, Языка и Литературы УрО РАН.

Šahhovskoi 1998 = Шаховской, Альберт. Контрапункт словесного и музыкального рядов (Бесермянские крези). Виктор Гацак (toim). Фольклор: Комплексная текстология. Москва: Наследие, lk 108-121.

Tolstaja 1985 = Толстая, Светлана. Деды в полесском народном календаре. Конференция "Балто-славянские этнокультурные и археологические древности. Погребальный обряд”: Тезисы докладов. Москва: Институт славяноведения и балканистики АН СССР, lk 81-83. 